Hydrol. Earth Syst. Sci., 17, 2161-2170, 2013

www.hydrol-earth-syst-sci.net/17/2161/2013/

doi:10.5194/hess-17-2161-2013

(C) Author(s) 2013. CC Attribution 3.0 License.

\title{
Determining spatial variability of dry spells: a Markov-based method, applied to the Makanya catchment, Tanzania
}

\author{
B. M. C. Fischer ${ }^{1}$, M. L. Mul ${ }^{2}$, and H. H. G. Savenije ${ }^{3}$ \\ ${ }^{1}$ Department of Geography, University of Zurich, Winterthurerstrasse 190, 8057 Zurich, Switzerland \\ ${ }^{2}$ UNESCO-IHE, Institute for Water Education, P.O. Box 3015, 2601 DA Delft, the Netherlands \\ ${ }^{3}$ Faculty of Civil Engineering and Geosciences, Delft University of Technology, P.O. Box 5048, \\ 2600 GA Delft, the Netherlands
}

Correspondence to: B. M. C. Fischer (benjamin.fischer@geo.uzh.ch)

Received: 7 September 2012 - Published in Hydrol. Earth Syst. Sci. Discuss.: 15 October 2012

Revised: 9 April 2013 - Accepted: 30 April 2013 - Published: 7 June 2013

\begin{abstract}
With a growing world population and a trend towards more resource-intensive diets, pressure on land and water resources for food production will continue to increase in the coming decades. Large parts of the world rely on rainfed agriculture for their food security. In Africa, $90 \%$ of the food production is from rainfed agriculture, generally with low yields and a high risk of crop failure. One of the main reasons for crop failure is the occurrence of dry spells during the growing season. Key indicators are the critical dry spell duration and the probability of dry spell occurrence.

In this paper a new Markov-based framework is presented to spatially map the length of dry spells for fixed probabilities of non-exceedance. The framework makes use of spatially varying Markov coefficients that are correlated to readily available spatial information such as elevation and distance to the sea. The dry spell map thus obtained is compared to the spatially variable critical dry spell duration, based on soil properties and crop water requirements, to assess the probability of crop failure in different locations.

The results show that in the Makanya catchment the length of dry spell occurrence is highly variable in space, even over relatively short distances. In certain areas the probability of crop failure reaches levels that make rainfed agricultural unsustainable, even close to areas where currently rainfed agriculture is successfully being practised.

This method can be used to identify regions that are vulnerable to dry spells and, subsequently, to develop strategies for supplementary irrigation or rainwater harvesting.
\end{abstract}

\section{Introduction}

Globally, increasing population causes increasing pressure on the available water resources, which represents a major challenge in water management (Falkenmark, 1997). In the case of sub-Saharan Africa, population is growing rapidly and a shift to a more land and water resource-intensive diet is expected (Savenije, 1998, 2000; WWAP, 2009), requiring more use of the resources. These resources vary both spatially and temporally, alternating wet and dry years, with large variations between different locations (e.g. Mul et al., 2009). Climate change is expected to aggravate the situation. At the same time, average yields produced by rainfed agriculture have not increased; despite decades of investments in improving smallholder agricultural practices, yields still fluctuate around 1 ton ha ${ }^{-1}$ (Rockström et al., 2004). With increasing urbanisation, average food production per capita is declining (Love et al., 2006). In rural areas, demographic pressure and the limited availability of arable land force people to move from areas where conditions are favourable to areas and ecosystems where conditions are less favourable or marginal (Enfors and Gordon, 2007).

In sub-Saharan Africa, rainfed agriculture is responsible for $90 \%$ of the food production and $80 \%$ of the population rely on it for a living (Rockström, 2000). However, rainfed agriculture has a high risk of crop failure with water as a main limiting factor (Savenije, 1998; Enfors et al., 2011; Makurira et al., 2011; Mutiro et al., 2006). The dependency on the irregular input of precipitation can cause a shortage of water, commonly known as droughts or dry spells (Savenije, 1998; 


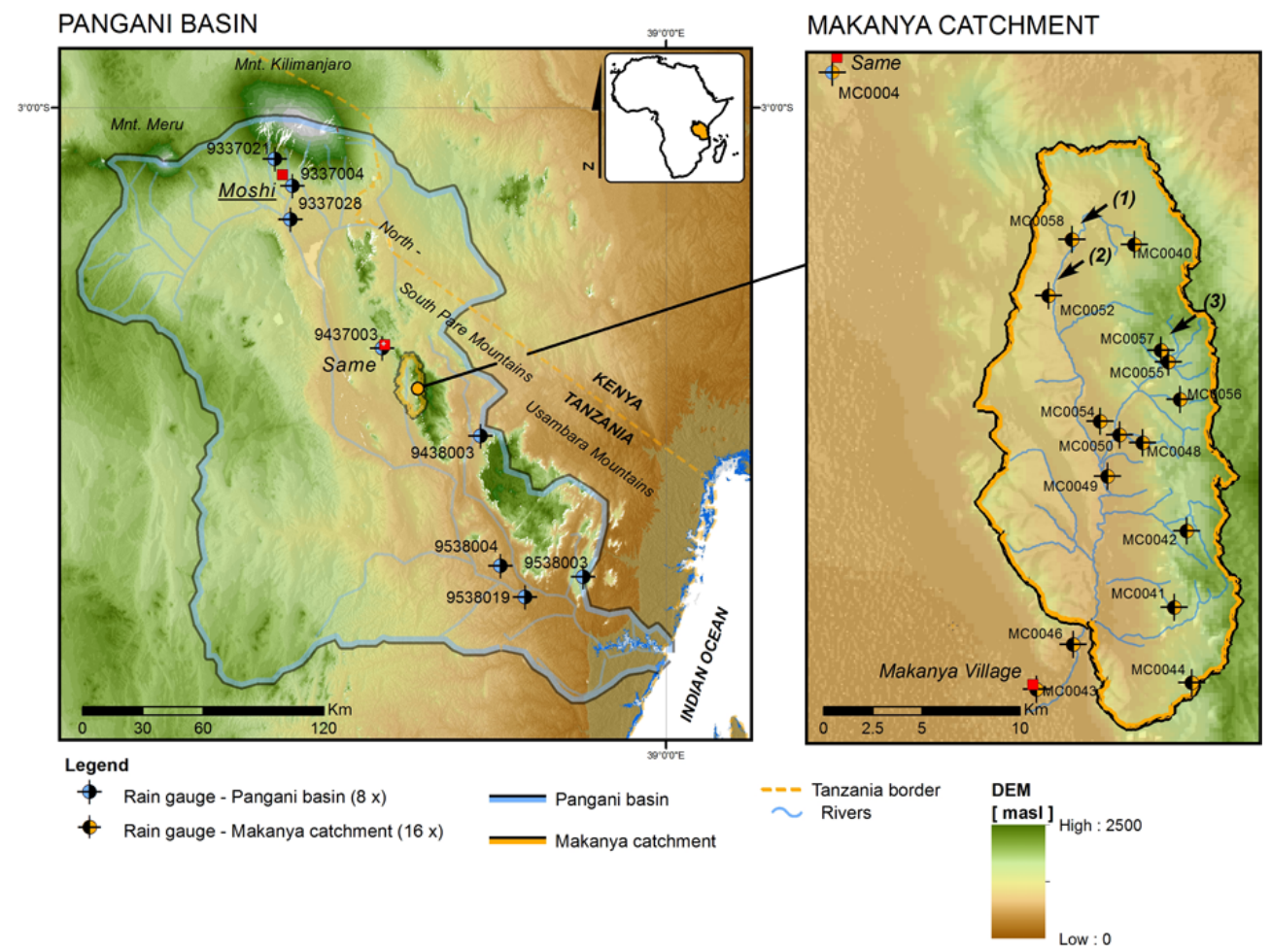

Fig. 1. The Pangani basin with the locations of the 8 rain gauges with daily rainfall data (1940-1989) (left map). The Makanya catchment with the locations of the 16 rain gauges with daily rainfall data (2005-2006) (right map). Numbers (1), (2) and (3) indicate the location for which the critical dry spell length was calculated.

Rockström, 2003; Enfors and Gordon, 2007). The definition of a drought is differently used in meteorology, hydrology and agriculture (Rossi et al., 1992). Each discipline has its user-specific thresholds for declaring a drought (Mishra and Singh, 2010; Rockström, 2003; Rossi et al., 1992; Wilhite and Glantz, 1985). For a drought not only the amount of water in terms of volume is relevant, but also its availability at the time it is mostly needed. Especially for rainfed agriculture, the knowledge of water fluxes and the alteration of wet and dry periods is essential (Rockström, 2000, 2003).

Mathugama and Peiris (2011) showed that many authors in different countries analysed long-term rainfall data related to dry spell characteristics with different techniques and varying data availability. Although sub-Saharan Africa has a long history of precipitation records, the spatial coverage of stations is coarse and data can be unreliable (De Groen and Savenije, 2006; Røhr and Killingtveit, 2003). Constrained by data availability, studies on precipitation usually give estimates on point-scale processes (Barron et al., 2003; ElSeed, 1987; Sivakumar, 1992), which are sometimes generalised for a region (Enfors and Gordon, 2007; Ochola and Kerkides, 2003). Different studies tried to move beyond the point scale and give estimates of risk on water stress for a region (Deni et al., 2008; Yoo et al., 2012). For Tanzania, Tilya and Mhita (2007) analysed the spatial and temporal frequency of wet and dry spells with 22 rain gauges spread over the country. This study shows the spatial structure of dry spells of Tanzania: long wet spells in the north-eastern highlands and long dry spells in the centre part of the country (Tilya and Mhita, 2007). At the same time, Mul et al. (2009) show that precipitation can be very localised and highly variable; this affects the reliability of interpolating precipitation estimates from long but coarse spatial resolution rain gauge data.

In addition to the meteorological input dynamics, sitespecific characteristics such as soil properties affect crop yields, as they determine water availability in the root zone (Enfors and Gordon, 2007). Crop water stress depends on the water-holding capacity of soil, water demand and antecedent wetness conditions (Barron et al., 2003). In rainfed agriculture, soil water storage can buffer for dry spells. If the water availability in the soil cannot buffer for the difference between supply and demand, the development of plants will be hampered, and in the worst case the plants will wither. This will happen if a dry spell lasts longer than the available soil moisture can supply. We defined this period as the critical dry spell.

The high spatial variability of both precipitation and soil properties affects the success of rainfed agriculture. In this paper we present a simple Markov-based framework to spatially map the length of dry spells for fixed probabilities of non-exceedance. The framework uses the Markov properties 


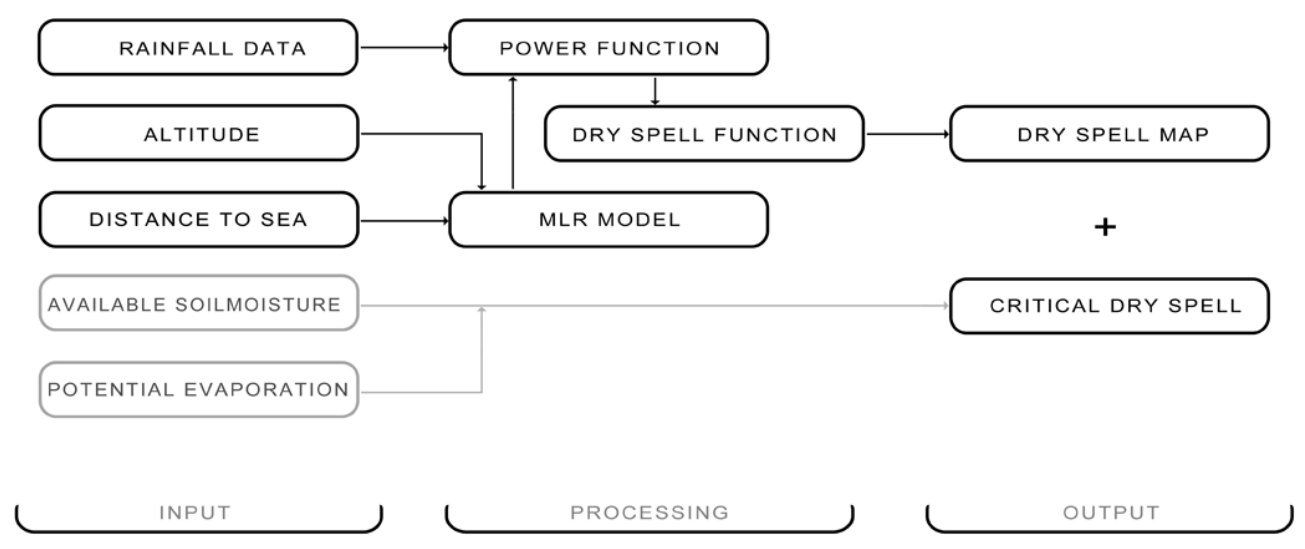

Fig. 2. Flow chart of the Markov-based framework for critical dry spell analysis. From left to right are the input variables which are processed to generate the output of dry spell length maps for fixed probabilities of non-exceedance. Combining this together with critical dry spell information, based on available soil moisture and evaporation, serves to assess the probability of crop failure.

of rainfall as applied by De Groen (2002) and De Groen and Savenije (2006) and regionalises them by using available spatial information of elevation and distance to the sea, creating a spatial map, showing the dry spell length with a given probability of occurrence. The critical dry spell duration, based on soil properties and crop water requirement, is then compared to this map to assess the probability of crop failure at specific locations.

The framework is demonstrated in the data-scarce Makanya catchment, where different sets of available spatial and temporal resolutions of rainfall data have been combined to map length of dry spell occurrence.

\section{Methodology}

\subsection{Study area}

The study area is a tributary in the Pangani basin $\left(43600 \mathrm{~km}^{2}\right)$, the Makanya catchment $\left( \pm 320 \mathrm{~km}^{2}\right)$, which is located in the South Pare Mountains (see Fig. 1). The area experiences a bimodal rainfall pattern (Griffiths, 1972; Rohr and Killingtveit, 2003), consisting of a short rainy season called Vuli (October-December), followed by a longer rainy season called Masika (March-May) (Tilya and Mhita, 2007). Rainfall in the catchment varies with altitude: the higher areas receive on average $\pm 800 \mathrm{~mm} \mathrm{yr}^{-1}$ compared to the lower regions with $\pm 550 \mathrm{~mm} \mathrm{yr}^{-1}$ (Mul et al., 2008).

In this area, the majority of the people are traditional small-scale farmers whose livelihoods depend on rainfed agriculture and supplementary irrigation (Makurira et al., 2007; Mul et al., 2011). Like other sub-Saharan regions, population growth leads to land pressure and an expansion of agricultural land into other types of ecosystems (Rockström et al., 2004; Enfors and Gordon, 2007). The dominant migration is from the higher elevation, with abundant water where land is becoming scarce, to more water-scarce regions in the valley. For most of the years, supplementary irrigation is required to obtain reasonable yields (Mul, 2009); the actual need for supplementary irrigation is related to the occurrence of dry spells at that particular location, and the water-holding capacity of the soils (Enfors and Gordon, 2007).

As Mul et al. (2009) show, rainfall is highly variable in this area. Farmers migrating to less favourable areas face two-fold challenges: the rainfall distribution (in terms of dry spell occurrences) and soil characteristics in the new location. Therefore we need to improve the knowledge on spatial and temporal rainfall characteristics in combination with site and crop characteristics. In this study we present a Markovbased framework which spatially maps the length of dry spells for fixed probabilities of non-exceedance.

\subsection{Markov-based framework for critical dry spell analysis}

The following Markov-based framework (see Fig. 2) has been applied to spatially map the length of dry spells for fixed probabilities of non-exceedance in the Makanya catchment for which a short but high spatial resolution data set on rainfall exists. Data of 16 rain gauges for the year 2006 were used for further analysis. However to be able to assess the probability of dry spell occurrences, long time series are required. In the Pangani basin, there are a number of stations that have up to $90 \mathrm{yr}$ of daily rainfall data (PBWO, 2007). A selection of rain gauges was made based on record length, data quality and consistency. This resulted in eight rain gauges with daily rainfall data covering the period of 1940-1989 (Fig. 1). The Markov chain properties for these stations were determined and then regionalised using a multiple linear regression (MLR) model using elevation and distance to the sea derived from the Seamless Shuttle Radar Topography Mission data (USGS, 2007). Using these spatially determined properties and the interpolated seasonal rainfall map for the Makanya catchment, maps are created showing the duration 
Table 1. Markov properties for both transition probabilities $p_{01}$ and $p_{11}$ for the eight rain gauges of the Pangani basin for Masika season, on monthly and seasonal basis.

\begin{tabular}{|c|c|c|c|c|c|c|c|c|c|}
\hline \multirow[t]{2}{*}{ trans.prop. } & \multirow[t]{2}{*}{ par. } & \multicolumn{8}{|c|}{ rain gauge } \\
\hline & & 9337004 & 9337021 & 9337028 & 9437003 & 9438003 & 9538003 & 9538004 & 9538019 \\
\hline \multicolumn{10}{|l|}{ Monthly } \\
\hline \multirow[t]{6}{*}{$p_{01}$} & $a_{\text {var a }}$ & 0.03 & 0.05 & 0.03 & 0.05 & 0.07 & 0.04 & 0.03 & 0.02 \\
\hline & $b_{\text {var a }}$ & 0.46 & 0.41 & 0.43 & 0.38 & 0.33 & 0.42 & 0.42 & 0.56 \\
\hline & $R^{2}$ & 0.90 & 0.94 & 0.68 & 0.89 & 0.55 & 0.92 & 0.80 & 0.92 \\
\hline & $\bar{a}_{\text {fixed }}$ & 0.04 & 0.04 & 0.04 & 0.04 & 0.04 & 0.04 & 0.04 & 0.04 \\
\hline & $b_{\text {fixed a }}$ & 0.42 & 0.44 & 0.39 & 0.41 & 0.43 & 0.44 & 0.39 & 0.39 \\
\hline & $R^{2}$ & 0.88 & 0.94 & 0.66 & 0.90 & 0.54 & 0.92 & 0.78 & 0.88 \\
\hline \multirow[t]{6}{*}{$p_{11}$} & $a_{\text {var a }}$ & 0.16 & 0.15 & 0.38 & 0.37 & 0.12 & 0.10 & 0.11 & 0.06 \\
\hline & $b_{\text {var a }}$ & 0.26 & 0.28 & 0.05 & 0.07 & 0.34 & 0.36 & 0.31 & 0.43 \\
\hline & $R^{2}$ & 0.90 & 0.89 & 0.66 & 0.53 & 0.84 & 0.86 & 0.81 & 0.83 \\
\hline & $\bar{a}_{\text {fixed }}$ & 0.18 & 0.18 & 0.18 & 0.18 & 0.18 & 0.18 & 0.18 & 0.18 \\
\hline & $b_{\text {fixed a }}$ & 0.24 & 0.25 & 0.22 & 0.24 & 0.25 & 0.26 & 0.23 & 0.21 \\
\hline & $R^{2}$ & 0.88 & 0.88 & 0.66 & 0.62 & 0.73 & 0.78 & 0.74 & 0.54 \\
\hline \multicolumn{10}{|l|}{ Seasonal } \\
\hline \multirow[t]{6}{*}{$p_{01}$} & $a_{\text {var a }}$ & 0.03 & 0.24 & 0.02 & 0.03 & 0.05 & 0.09 & 0.02 & 0.01 \\
\hline & $b_{\text {var a }}$ & 0.35 & 0.06 & 0.40 & 0.37 & 0.32 & 0.23 & 0.42 & 0.49 \\
\hline & $R^{2}$ & 0.80 & 0.11 & 0.84 & 0.64 & 0.84 & 0.30 & 0.77 & 0.85 \\
\hline & $\bar{a}_{\text {fixed }}$ & 0.06 & 0.06 & 0.06 & 0.06 & 0.06 & 0.06 & 0.06 & 0.06 \\
\hline & $b_{\text {fixed a }}$ & 0.26 & 0.26 & 0.23 & 0.24 & 0.28 & 0.29 & 0.25 & 0.26 \\
\hline & $R^{2}$ & 0.79 & 0.37 & 0.90 & 0.59 & 0.79 & 0.30 & 0.61 & 0.65 \\
\hline \multirow[t]{6}{*}{$p_{11}$} & $a_{\text {var a }}$ & 0.16 & 0.29 & 0.10 & 0.07 & 0.08 & 0.35 & 0.10 & 0.16 \\
\hline & $b_{\text {var a }}$ & 0.22 & 0.15 & 0.28 & 0.37 & 0.35 & 0.12 & 0.29 & 0.22 \\
\hline & $R^{2}$ & 0.60 & 0.92 & 0.31 & 0.94 & 0.73 & 0.53 & 0.76 & 0.19 \\
\hline & $\bar{a}_{\text {fixed }}$ & 0.15 & 0.15 & 0.15 & 0.15 & 0.15 & 0.15 & 0.15 & 0.15 \\
\hline & $b_{\text {fixed a }}$ & 0.23 & 0.25 & 0.21 & 0.23 & 0.24 & 0.25 & 0.22 & 0.21 \\
\hline & $R^{2}$ & 0.60 & 0.86 & 0.30 & 0.90 & 0.72 & 0.23 & 0.73 & 0.24 \\
\hline
\end{tabular}

of a dry spell for a particular probability of occurrence $(20$, 50 and $80 \%$ ). At three locations, the probability of dry spells was compared to the critical dry spell length, based on soil properties and potential evaporation. In order to assess the probability of a critical dry spell occurring at these locations, the dry spell length was drawn as a function of the probability.

\subsection{Spatially distributed Markov chain properties}

Dry spells are defined as a number of consecutive days without rainfall, and consecutive days with rainfall are called wet spells. In this study we used a threshold of $0.1 \mathrm{~mm} \mathrm{day}^{-1}$ to distinguish between a wet and a dry day, similar to De Groen (2002), Madamombe (1994) and El-Seed (1987). This threshold was used as we focussed on the meteorological dry spells. In future applications the threshold set should be compatible with the field of application and their end users (e.g. for agricultural applications a threshold of $1 \mathrm{~mm} \mathrm{day}^{-1}$ may be more appropriate, e.g. Enfors and Gordon, 2007, used $\left.0.8 \mathrm{~mm} \mathrm{day}^{-1}\right)$. The interchange between wet and dry days can be stochastically described by Markov chains (Gabriel and Neumann, 1962). This study adopted first-order twostate Markov chains to describe wet and dry spells where the probability of a wet or dry day only depends on whether the previous day was a wet or dry day. This method was already successfully adopted in the region by several authors (De Groen and Savenije, 2006; Biamah et al., 2005; Barron et al., 2003; De Groen, 2002; Madamombe, 1994; Sharma, 1996). In Markov chains, the transition probability is defined as the ratio of the number of transitions from one state to another $t_{x y}$ to the total number of transitions $t_{x}$ (see Eq. 1). In this way, the probability that a dry day is followed by a wet day $t_{01}$ can be written as Eq. (2), and the probability of a wet day after a wet day $t_{11}$ as Eq. (3). 

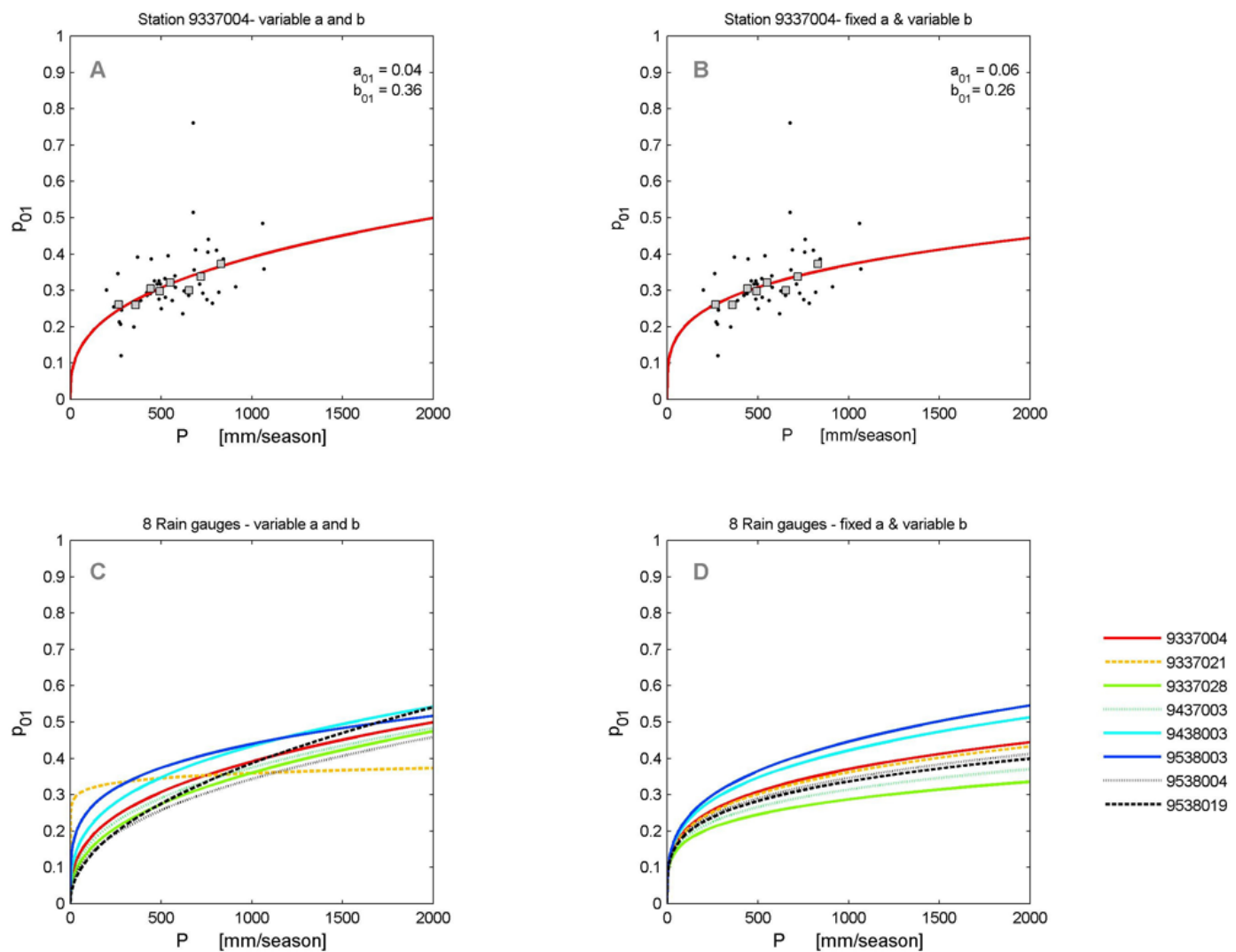

Fig. 3. Transition probabilities $p_{01}$ vs. precipitation in Masika season. Scatter plot of one rain gauge 9337004 with (A) variable $a$ and $b$, (B) fixed $a$ and variable $b$. Dots represent individual seasons, and squares represent the median value per rainfall class. Plot of all eight rain gauges of the Pangani basin with (C) variable $a$ and $b$, (D) fixed $a$ and variable $b . R^{2}$ values are listed in Table 1 .

$$
\begin{aligned}
& p_{x y}=\frac{\sum t_{x y}}{\sum t_{x}} \\
& p_{01}=\frac{\sum t_{01}}{\sum t_{0}} \\
& p_{11}=\frac{\sum t_{11}}{\sum t_{1}}
\end{aligned}
$$

De Groen (2002) showed that individual monthly transition probabilities $p_{01}$ and $p_{11}$ can be expressed as a power function of the monthly rainfall $P\left(\mathrm{~mm}\right.$ month $\left.^{-1}\right)$ (see Eqs. 4 and 5).

$$
\begin{aligned}
& p_{01}=a_{01} P^{b_{01}} \\
& p_{11}=a_{11} P^{b_{11}}
\end{aligned}
$$

From the work of De Groen and Savenije (2006), we observed that the power function coefficients $a$ and $b$, describing the Markov probabilities, are station dependent. In this study we derived a relationship between these Markov coefficients and their spatial location. To do so we fixed the coefficients $a_{01}$ and $a_{11}$ at the average value of all stations (see Eqs. 6 and 7):

$$
\begin{aligned}
& p_{01}=\bar{a}_{01} P^{b_{01}} \\
& p_{11}=\bar{a}_{11} P^{b_{11}} .
\end{aligned}
$$

Subsequently we allowed the exponent, $b$, to vary in space. We applied a simple formula whereby the Markov coefficient $\boldsymbol{b}(-)$ is a function of altitude $\mathbf{H}(\mathrm{m})$ and distance to sea $\mathbf{D}(\mathrm{m})$ with $\alpha, \beta$ and $\epsilon$ as the regression parameters (see Eq. 8):

$\boldsymbol{b}=\alpha+\beta \mathbf{H}+\epsilon \mathbf{D}$.

The values for $\alpha, \beta$ and $\epsilon$, are derived by performing a multiple linear regression using spatial information on altitude and distance to the sea. In combination with an interpolated seasonal rainfall map, using ordinary co-kriging, the spatially distributed transition probabilities $p_{01}$ and $p_{11}$ for ungauged locations can be obtained.

\subsection{Probability of dry spell duration}

For rainfed farming, the critical factor determining crop failure is the maximum dry spell duration that can be expected during a growing season. De Groen (2002) showed that the probability $p$ of a maximum dry spell length $n_{\text {dry,max }}$ (days) 
can be written as a cumulative density function based on transition probabilities $p_{01}$ and $p_{11}, n_{\mathrm{m}}$ (days month $^{-1}$ ) and number of $n$ (days) (Eq. 9):

$$
\begin{aligned}
p & \left(n_{\mathrm{dry}, \max } \leq n\right) \\
\quad & \exp \left[-n_{\mathrm{m}}\left(\frac{p_{01}}{1-\left(p_{11}-p_{01}\right)}\right)\left(1-p_{11}\right)\left(1-p_{01}\right)^{n}\right] .
\end{aligned}
$$

Assuming that a dry spell is not longer than the number of days of a month or season $n_{\mathrm{S}}\left(\right.$ days season ${ }^{-1}$ ), De Groen (2002) showed that rewriting Eq. (9) for a point with given probability of non-exceedance $p_{\text {ne }}(-)$ results in the maximum dry spell length $n_{\text {dry, max }}$ (days) (Eq. 10):

$$
n_{\text {dry } \max }\left(p_{\text {ne }}\right)=\frac{\ln \left(\frac{\ln \left(p_{\text {ne }}\right)}{-n_{\mathrm{s}}\left(\frac{p_{01}}{p_{11}-p_{01}}\right)\left(1-p_{11}\right)}\right)}{\ln \left(1-p_{01}\right)} .
$$

Using this equation with the interpolated transition probabilities $p_{01}$ and $p_{11}$, the dry spell length for ungauged locations can be derived. The result is a spatial map with dry spell length for a given probability of occurrence.

\subsection{Critical dry spell}

The critical dry spell length is the time period that the ecosystem can bridge. It is the ratio between the available soil moisture and the transpiration rate of the vegetation (see Eq. 11). If the transpiration demand is larger than the available soil moisture, the development of the plant will be hampered or, in the worst case, the plant will wilt. The critical dry spell length $n_{\text {cr }}$ (days) can thus be calculated at every point in space as the ratio of the available soil moisture $\theta(\mathrm{mm})$ to the potential evaporation $E_{\mathrm{p}}\left(\mathrm{mm} \mathrm{day}^{-1}\right)$ :

$n_{\mathrm{cr}}=\frac{\theta}{E_{\mathrm{p}}}$.

Due to data limitations of spatially distributed soil moisture and evaporation measurements in the Makanya catchment, the critical dry spell length has been calculated for only three locations. Location 1 and 2 were selected in the lower middle part of the catchment with coarse erosion sediments, while location 3 was selected for higher altitudes with clayey soils (see Fig. 1 for locations). Soil moisture measurements in the catchment indicated that the maximum soil moisture content varies between 8 and 12\% (Makurira et al., 2010). To estimate the available soil moisture stock, it is assumed that maize, the staple crop grown in the area, has a root depth of approximately $500 \mathrm{~mm}$. With the assumption that at the beginning of the rainy seasons this stock has been replenished, the available soil moisture for the crop is around $10 \%$ $(50 \mathrm{~mm})$. Data collected from a Class A-pan in locations 2 (valley) and 3 (mountain) were used to determine the potential evaporation (see Fig. 4 for locations). The critical dry spell length is then compared with maximum dry spell length derived from Eq. (11) for different probability values.
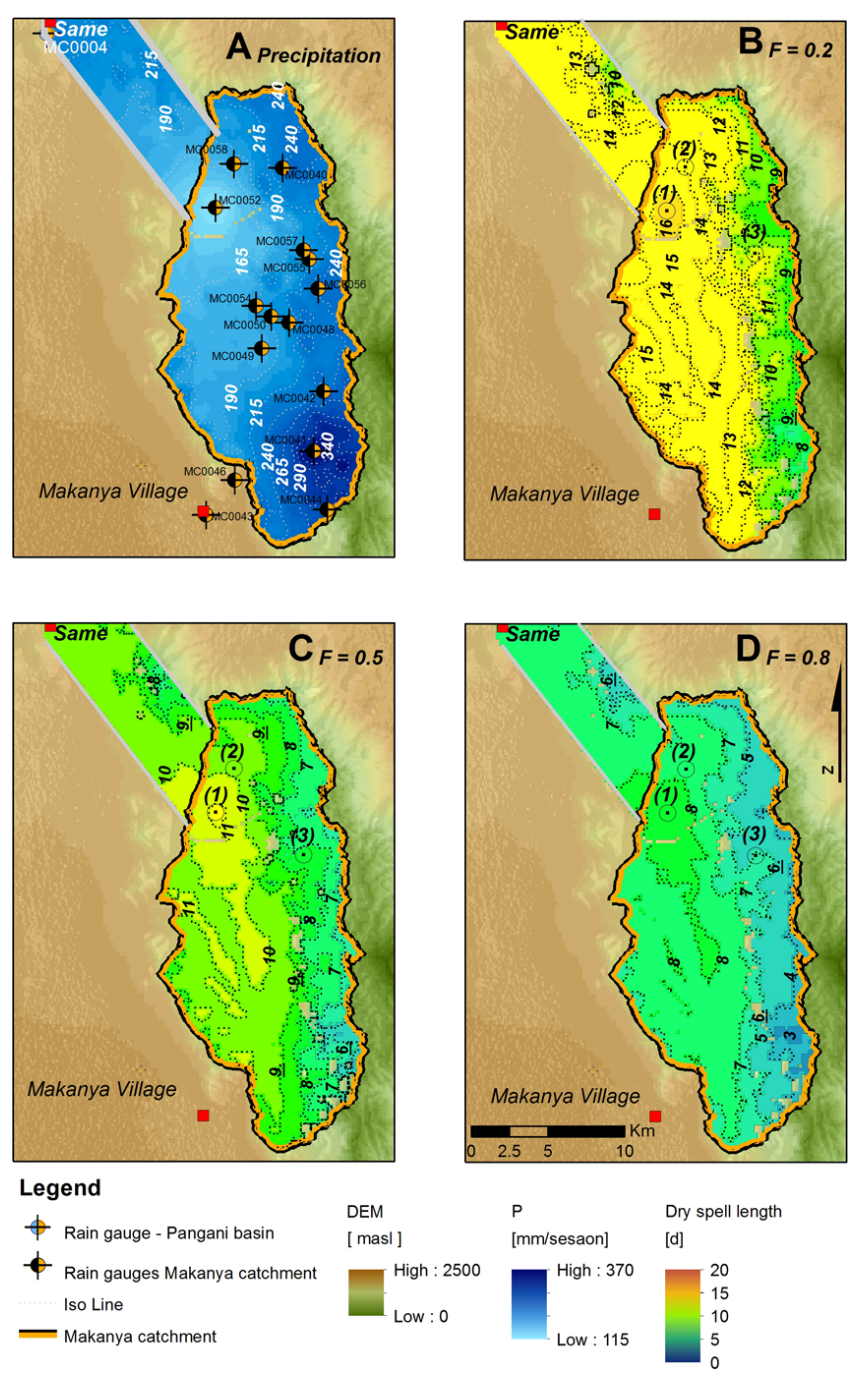

Fig. 4. (A) Ordinary co-kriging-derived synthetic rainfall map for rain season Masika. (B-D) Map with dry spell length for fixed probabilities of non-exceedance: $p_{\text {ne }}=80 \%, 50 \%$ and $20 \%$. Numbers in brackets indicate locations for which the critical dry spell was calculated.

\section{Results}

\subsection{Markov properties}

The Markov properties were determined by testing two methods using the eight available rain gauges of the Pangani basin (period 1940-1989, Fig. 1):

1. For every individual month (March, April and May), the transition probabilities $\left(p_{01}\right.$ and $\left.p_{11}\right)$ are expressed as function of their monthly rainfall amounts (all months are presented in one graph). This resembles a seasonal average power function with parameters $a, b$ and $R^{2}$ (Table 1) used in Eqs. (4) to (7). 
Table 2. Parameters and statistics of the seasonal derived multiple linear regression model of the Pangani basin.

\begin{tabular}{ccccccc}
\hline & parameter & $\begin{array}{c}\text { par. } \\
\text { value }\end{array}$ & \multicolumn{2}{c}{$\begin{array}{c}95 \% \text { confidence } \\
\text { intervals }\end{array}$} & $\begin{array}{c}R^{2} \\
\text { statistic }\end{array}$ & $\begin{array}{l}F \\
\text { statistic }\end{array}$ \\
\hline \multirow{2}{*}{$b_{01}$} & $\alpha$ & $2.48 \times 10^{-1}$ & $1.66 \times 10^{-1}$ & $3.29 \times 10^{-1}$ & 0.41 & 1.41 \\
& $\beta$ & $5.11 \times 10^{-5}$ & $-7.47 \times 10^{-5}$ & $1.77 \times 10^{-4}$ & & \\
& $\varepsilon$ & $-1.43 \times 10^{-4}$ & $-3.88 \times 10^{-4}$ & $1.03 \times 10^{-4}$ & & \\
\hline \multirow{2}{*}{$b_{11}$} & $\alpha$ & $2.07 \times 10^{-1}$ & $1.61 \times 10^{-1}$ & $2.53 \times 10^{-1}$ & 0.54 & 2.37 \\
& $\beta$ & $5.15 \times 10^{-5}$ & $-1.93 \times 10^{-5}$ & $1.22 \times 10^{-4}$ & & \\
& $\varepsilon$ & $-7.99 \times 10^{-5}$ & $-2.18 \times 10^{-4}$ & $5.82 \times 10^{-5}$ & & \\
\hline
\end{tabular}

Table 3. Ordinary co-kriging models and cross validation results for Masika season, ME (mean error), RMSE (root mean square error), ASE (average standard error), MSE (mean standardized error), RMSSE (root-mean-squared standardized error).

\begin{tabular}{llrrrrr}
\hline Interpolation type & Model & ME & RMSE & ASE & MSE & RMSSE \\
\hline \multirow{4}{*}{ Ordinary Co-Kriging } & Exponential & -5.07 & 59.46 & 57.68 & -0.07 & 1.03 \\
& Stable & -9.80 & 71.63 & 46.5 & -0.15 & 1.58 \\
& Spherical & -5.78 & 61.18 & 51.05 & -0.08 & 1.23 \\
& Gaussian & -10.03 & 71.43 & 46.74 & -0.16 & 1.56 \\
\hline
\end{tabular}

2. For a season as a whole (March-May), the transition probabilities $\left(p_{01}\right.$ and $\left.p_{11}\right)$ are expressed as a function of the seasonal rainfall amounts to derive the seasonal parameters $a, b$ and $R^{2}$ (Table 1) using Eqs. (4) to (7).

Figure $3 \mathrm{a}$ and $\mathrm{b}$ for the seasonal transition probability values show a large scatter. To demonstrate the stability of the power function, the approach of De Groen and Savenije (2006) was followed. Here individual transition probabilities were clustered in 6 rainfall classes with their median transition probabilities plotted using the grey squares in Fig. 3a and b. The transition probabilities expressed on a monthly basis show better correlation (see Table 1). However, for the further analysis we will focus on the seasonal Markov properties, as we intend to demonstrate the framework related to the agricultural production, which is a function of seasonal precipitation. Figure 3 and Table 1 show the variability of the coefficients $a$ and $b$ of the power function of the transitional probabilities calculated using Eqs. (4)-(7). The coefficient of determination $\left(R^{2}\right)$ (Eq. 12) was calculated to determine how well the power function approximates the observed data points, using $y_{i}, \hat{y}$ and $\bar{y}$ as the original, modelled and mean of the original values respectively.

$R^{2}=1-\frac{\sum_{i}^{n}\left(y_{i}-\hat{y}\right)^{2}}{\sum_{i}^{n}\left(y_{i}-\bar{y}\right)^{2}}$

The results of the multiple linear regression model, using the eight rainfall stations in the Pangani basin, are presented in Table 2. The coefficient of determination $\left(R^{2}\right)$ and $F$ statistics (Eq. 13) were calculated to determine how well the MLR model simulates the observed values and can capture the variance of the observed data (for $F>1$, the model captures the variance adequately). The $F$ statistics were calculated using $J$ as the number of independent variables (in our case two, the distance to sea and altitude) and $K$ the number of predictors, in our case the number of rain gauges (8 rain gauges).

$$
F=\frac{\sum_{i}^{n}\left(\hat{y}_{i}-\bar{y}\right)^{2} / J}{\sum_{i}^{n}\left(y_{i}-\hat{y}\right)^{2} /(K-J-1)}
$$

These coefficients are subsequently used in the Makanya catchment to obtain the spatially variable Markov coefficients $b_{01}$ and $b_{11}$. To obtain the spatial transition probabilities $p_{01}$ and $p_{11}$, the daily rainfall data set in the Makanya catchment (16 stations) was regionalised to produce rainfall maps. The Masika seasons used (2006) were considered "wet" seasons with above average precipitation amounts. To compensate for this, the rainfall amounts were scaled to an average of the rainfall season. The scaling factor is derived by dividing the seasonal rainfall value of the Masika season in 2006 by the long-term average amounts for the rain gauge located in Same (1940-2007) resulting in a factor of $0.55(-)$. All rain gauge data of the Makanya catchment for Masika season 2006 were scaled by this factor. This new "synthetic" rainfall data have been used for ordinary co-kriging to make a rainfall map for further analysis. Due to the slightly better performance, the exponential model was chosen (see Table 3 for cross validation and Fig. 4a for the map). The combination of the fixed coefficients, $\bar{a}_{01}$ and $\bar{a}_{11}$, the spatially distributed coefficients, $b_{01}$ and $b_{11}$, with the seasonal rainfall map, making use of the power functions of Eqs. (6) and (7), provides the spatially distributed transition probabilities $p_{01}$ and $p_{11}$ to be used in Eq. (10) to map the dry spell length for fixed probabilities of non-exceedance. 

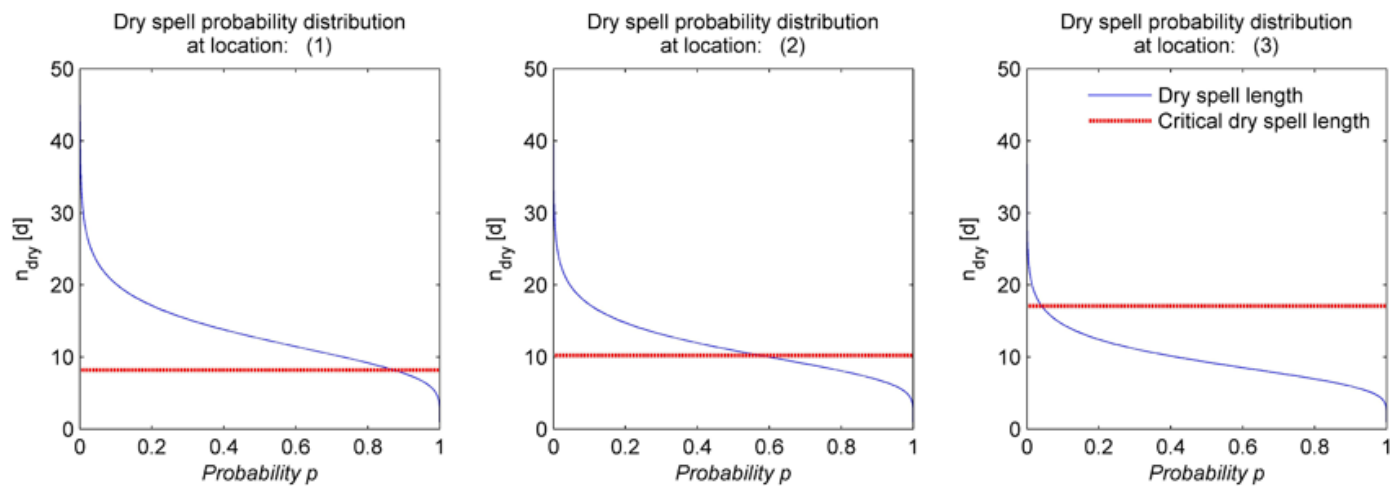

Fig. 5. Cumulative dry spell distribution for the three locations indicated in Fig. 4. This can be obtained from Eq. (10) calculating for each probability of non-exceedance ( $\left.p_{\text {ne }}\right)$ its $n_{\text {dry, } \max }$.

\subsection{Dry spell maps}

Three different dry spell maps (Fig. 4b-d) were compiled using the interpolated rainfall map of the Makanya catchment (Fig. 4a). These three figures show the spatial distribution of dry spell length for different probabilities of non-exceedance: $p_{\text {ne }}=80 \%, 50 \%$ and $20 \%$ (based on Eq. 9). A high spatial variability of precipitation and dry spells is visible within the Makanya catchment. In the higher parts of the catchment, rainfall amounts are higher and the probability of long dry spells is lower. This information is combined with the information on critical dry spells length for the three locations, which ranges between 8 and 17 days depending on the soil type and potential evaporation (see Table 4 and Fig. 5).

The probability of occurrence of a critical dry spell for the three sites ranges between $5 \%$ for the higher areas and $90 \%$ for the lower areas (see Fig. 5). Not only is this a result of the higher probability of dry spells, but this also is due to the lower soil-moisture-holding capacities in the lower areas.

The results indicate that not only are the areas in the valley affected by the higher probability of occurrence of dry spells, but also these areas are more easily affected by dry spells due to the soil properties and higher potential evaporation.

\section{Discussion and conclusion}

The presented Markov-based framework clearly shows the high spatial variability of dry spell length. Previous research focussed on evaluating point data, which is often very coarse. In many areas, the required information is insufficient to assess the spatial vulnerability of local agriculture to dry spell occurrences. The results presented are based on parameters determined using the Masika season as a whole. As we showed in Sect. 3.1, the transition probabilities using monthly values showed a better correlation, but since farmers require seasonal rather than monthly information we focussed on the Masika season. We applied the same approach to the Vuli season, but the results were not as good as for
Table 4. Values of critical dry spell length $n_{\mathrm{cr}}$ for the three locations indicated in Fig. 4.

\begin{tabular}{cccccc}
\hline location & $\begin{array}{c}\theta \\
\text { available } \\
{[\%]}\end{array}$ & $\begin{array}{c}D \\
\text { root depth } \\
{[\mathrm{mm}]}\end{array}$ & $\begin{array}{c}\theta \text { available } \\
\text { to crop } \\
{[\mathrm{mm}]}\end{array}$ & $\begin{array}{c}E_{\mathrm{p}} \\
{\left[\mathrm{mm} \mathrm{d}^{-1}\right]}\end{array}$ & $\begin{array}{c}n_{\mathrm{cr}} \\
{[d]}\end{array}$ \\
\hline 1 & 8 & 500 & 40 & 4.9 & 8.2 \\
2 & 10 & 500 & 50 & 4.9 & 10.2 \\
3 & 12 & 500 & 60 & 3.5 & 17.1 \\
\hline
\end{tabular}

the Masika season. In particular the multiple linear regression model performed worse due to the fact that the main wind direction during the Vuli season is north and rainfall is therefore not related to the distance to the sea (which is located east of the catchment). As a result, an alternative multiple linear regression model may have to be developed for the Vuli season. The framework, however, requires a substantial amount of short-term data to be able to spatially distribute the Markov chain properties. In addition, the use of an above average season of Masika in 2006 and its dry spell map may underestimate the situation for certain years. Nevertheless compared to Tilya and Mhita (2007) the dry spell maps clearly demonstrate the regional variability and underline the need for spatially distributed dry spell analysis.

In applying this approach we have used average values from Class A-pan evaporation as a proxy for potential evaporation. Although evaporation is a dynamic process and not constant in time, we used the average daily $E_{\mathrm{p}}$ ratio in a way to express the typical critical dry spell length rather than developing a dynamic model incorporating the long stochastic time series of $E_{\mathrm{p}}$. We realise this is a simplification of the natural processes, but it was used to demonstrate the method, rather than provide absolute values. The framework is independent of the method used to determine the potential evaporation or the available soil moisture. The essence is that both the meteorologically expected dry spell length and the critical dry spell length vary in space and that the matching of 
these two quantities provides an indication of areas where farmers have difficulty achieving a reliable yield.

This paper demonstrates a framework for assessing the spatial distribution of critical dry spells in a data-scarce environment. The results showed that within a $5 \mathrm{~km}$ radius, the probability of the occurrence of a critical dry spell can range between 5 and $90 \%$. This is both the consequence of varying soil conditions and potential evaporation, which lead to a wide range of critical dry spell length, between $8-17$ days. In addition, in the valley with lower rainfall amounts, the probability of dry spells is also higher. This combination - low soil water content, high potential evaporation and long dry spell occurrences - contributes to the high vulnerability of the valley to droughts $(90 \%)$. At the same time, in this area, access to surface water to supplement rainfall is limited. In contrast, at location 3 in the mountains, dry spell occurrences are not frequent, soil properties are good and potential evaporation is low. In addition, surface water is plentiful to supplement rainfall.

Using the spatial information on dry spell occurrence in water management provides opportunities to develop new water management strategies by (1) indicating potentially water-scarce regions, (2) developing techniques to improve soil characteristics or decrease non-productive evaporation fluxes and/or (3) increasing storage to bridge dry spells or decrease the vulnerability to dry spells.

This study sets the first step to use available rainfall data to reveal more detailed spatial patterns of dry spell occurrence. The next step would consist of developing spatially distributed soil and potential evaporation maps and of combining these with dry spell maps for the entire region, resulting in a spatially distributed critical dry spell map.

Acknowledgements. This research was part of the System Innovations in Integrated Watershed Management (SSI) Programme of UNESCO-IHE. Special thanks to the TU Delft - Laminga Fonds for contributing towards the fieldwork in the Makanya catchment. Pangani Basin Water Office gave access to the Pangani rainfall data, and we thank the SSI staff for their field assistance and interesting discussions. Special thanks deserve the farmers of the Makanya catchment who collected every day the rain gauge data and Ilaria Clemenzi for proofreading the manuscript. We would like to thank the anonymous Referee \#1 and \#2 as well as J. Bazrafshan for their review and valuable notes to improve the manuscript.

Edited by: B. Schaefli

\section{References}

Barron, J., Rockström, J., Gichuki, F., and Hatibu, N.: Dry spell analysis and maize yields for two semi-arid locations in East Africa, Agr. Forest Meteorol., 117, 23-37, doi:10.1016/S01681923(03)00037-6, 2003.

Biamah, E. K., Sterk, G., and Sharma, T. C.: Analysis of agricultural drought in Iiuni, Eastern Kenya: Application of a Markov model, Hydrol. Process., 19, 1307-1322, doi:10.1002/hyp.5556, 2005.

De Groen, M. M.: Modelling interception and transpiration at monthly time steps; introducing daily variability through Markov chains, PhD thesis Delft University of Technology, The Netherlands, 2002.

De Groen, M. M. and Savenije, H. H. G.: A monthly interception equation based on the statistical characteristics of daily rainfall, Water Resour. Res., 42, W12417,doi:10.1029/2006WR005013, 2006.

Deni, S. M., Jemain, A. A., and Ibrahim, K.: The spatial distribution of wet and dry spells over Peninsular Malaysia, Theor. Appl. Climatol., 94, 163-173, doi:10.1007/s00704-007-0355-8, 2008.

El-Seed, A. G.: An application of Markov Chain Model for wet and dry spell probabilities at Juba in Southern Sudan, Geo J. Lib., 15, 420-424, doi:10.1007/BF00189081, 1987.

Enfors, E. I. and Gordon, L. J.: Analyzing resilience in dryland agro-ecosystems: A case study of the Makanya catchment in Tanzania over the past 50 years, Land Degrad. Develop., 18, 680696, doi:10.1002/ldr.807, 2007.

Enfors, E. I., Barron, J., Makurira, H., Rockström, J., and Tumbo, S.: Yield and soil system changes from conservation tillage in dryland farming: A case study from North Eastern Tanzania, Agr. Water Manage., 98, 1687-1695, doi:10.1016/j.agwat.2010.02.013, 2011.

Falkenmark, M.: Society's interaction with the water cycle: a conceptual framework for a more holistic approach, Hydrol. Sci. J., 42, 451-466, doi:10.1080/02626669709492046, 1997.

Gabriel, K. R. and Neumann, J.: A Markov chain model for daily rainfall occurrence at Tel Aviv, Q. J. Roy. Meteor. Soc., 88, 9095, doi:10.1002/qj.49708837511, 1962.

Griffiths, J. F.: Climates of Africa - World Survey of Climatology, Vol. 10, 604 pp., Elsevier Publishing, Amsterdam, 1972.

Love, D., Twomlow, S., Mupangwa, W., van der Zaag, P., and Gumbo, B.: Implementing the millennium development food security goals - Challenges of the southern African context, Phys. Chem. Earth, 31, 731-737, doi:10.1016/j.pce.2006.08.002, 2006.

Madamombe, E. K.: A comparison of Neyman-Scott rectangular pulses and Markov chain stochastic rainfall models using data from Tanzania, MSc Thesis, University of Newcastleupon-Tyne, United Kingdom, 1994.

Makurira, H., Mul, M. L., Vyagusa, N. F., Uhlenbrook, S., and Savenije, H. H. G.: Evaluation of community-driven smallholder irrigation in dryland South Pare Mountains, Tanzania: A case study of Manoo micro dam, Phys. Chem. Earth, 32, 1090-1097, doi:10.1016/j.pce.2007.07.020, 2007.

Makurira, H., Savenije, H. H. G., and Uhlenbrook, S.: Modelling field scale water partitioning using on-site observations in subSaharan rainfed agriculture, Hydrol. Earth Syst. Sci., 14, 627638, doi:10.5194/hess-14-627-2010, 2010.

Makurira, H., Savenije, H. H. G., Uhlenbrook, S., Rockström, J., and Senzanje, A.: The effect of system innovations on water productivity in subsistence rainfed agricultural systems 
in semi-arid Tanzania, Agr. Water Manage., 98, 1696-1703, doi:10.1016/j.agwat.2011.05.003, 2011.

Mathugama, S. C. and Peiris, T. S. G.: Critical Evaluation of Dry Spell Research, Int. J. Basic Appl. Sci., 11, 153-160, 2011.

Mishra, A. K. and Singh, V. P.: A review of drought concepts, J. Hydrol., 391, 202-216, doi:10.1016/j.jhydrol.2010.07.012, 2010.

Mul, M. L.: Understanding hydrological processes in an ungauged catchment in sub-Saharan Africa, PhD thesis, UNESCO-IHE, Delft, The Netherlands, 2009.

Mul, M. L., Mutiibwa, R. K., Uhlenbrook, S., and Savenije, H. H. G.: Hydrograph separation using hydrochemical tracers in the Makanya catchment, Tanzania, Phys. Chem. Earth, 33, 151-156, doi:10.1016/j.pce.2007.04.015, 2008.

Mul, M. L., Savenije, H. H. G., and Uhlenbrook, S.: Spatial rainfall variability and runoff response during an extreme event in a semi-arid catchment in the South Pare Mountains, Tanzania, Hydrol. Earth Syst. Sci., 13, 1659-1670, doi:10.5194/hess-131659-2009, 2009.

Mul, M. L., Kemerink, J. S., Vyagusa, N. F., Mshana, G., van der Zaag, P., and Makurira, H.: Water allocation practices among smallholder farmers in South Pare Mountains, Tanzania; The issue of scale, Agr. Water Manage., 98, 1752-1760, doi:10.1016/j.agwat.2010.02.014, 2011.

Mutiro, J., Makurira, H., Senzanje, A., and Mul, M. L.: Water productivity analysis for smallholder rainfed systems: A case study of Makanya catchment, Tanzania, Phys. Chem., 31, 901-909, doi:10.1016/j.pce.2006.08.019, 2006.

Ochola, W. O. and Kerkides, P.: A Markov chain simulation model for predicting critical wet and dry spells in Kenya: Analysing rainfall events in the Kano Plains, Irrigat. Drain., 52, 327-342, doi:10.1002/ird.94, 2003.

PBWO, Pangani Basin Water Office: Pangani basin rain gauge data (daily and monthly rainfall data), Moshi, PBWO, 2007.

Rockström, J.: Water resources management in smallholder farms in Eastern and Southern Africa: An overview, Phys. Chem. Earth, 25, 275-283, doi:10.1016/S1464-1909(00)00015-0, 2000.

Rockström, J.: Resilience building and water demand management for drought mitigation, Phys. Chem. Earth, 28, 869-877, doi:10.1016/j.pce.2003.08.009, 2003.

Rockström, J., Folke, C., Gordon, L., Hatibu, N., Jewitt, G., Penning de Vries, F., Rwehumbiza, F., Sally, H., Savenije, H., and Schulze, R.: A watershed approach to upgrade rainfed agriculture in water scarce regions through Water System Innovations: An integrated research initiative on water for food and rural livelihoods in balance with ecosystem functions, Phys. Chem. Earth, 29, 1109-1118, doi:10.1016/j.pce.2004.09.016, 2004.
Røhr, P. C. and Killingtveit, A.: Rainfall distribution on the slopes of Mt Kilimanjaro, Hydrol. Sci. J., 48, 65-77, doi:10.1623/hysj.48.1.65.43483, 2003.

Rossi, G., Benedini, M., Tsakiris, G., and Giakoumakis, S.: On regional drought estimation and analysis, Int. Ser. Prog. Wat. Res., 6, 249-277, doi:10.1007/BF00872280, 1992.

Savenije, H. H. G.: "How do we feed a growing world population in a situation of water scarcity?", Key note paper presented in: "Water-The Key to Socio-economic Development and Quality of Life", at the 8th Stockholm Symposium, 10-13 August 1998, 49-58, SIWI, Stockholm, 1998.

Savenije, H. H. G.: Water scarcity indicators; the deception of the numbers, Phys. Chem. Earth, 25, 199-204, doi:10.1016/S14641909(00)00004-6, 2000.

Sharma, T. C.: Simulation of the Kenyan longest dry and wet spells and the largest rain-sums using a Markov model, J. Hydrol., 178, 55-67, doi:10.1016/0022-1694(95)02827-7, 1996.

Sivakumar, M. V. K.: Empirical analysis of dry spells for agricultural applications West Africa, J. Climate, 5, 532-539, doi:10.1175/1520-0442(1992)005<0532:EAODSF > 2.0.CO;2, 1992.

Tilya, F. and Mhita, M.: Frequency of Wet and Dry Spells in Tanzania, in: Climate and Land Degradation SE - 10, edited by: Sivakumar, M. K. and Ndiang'ui, N., 197-204, Springer Berlin Heidelberg, doi:10.1007/978-3-540-72438-4_10, 2007.

USGS: Seamless Data Distribution System (SDDS) 1 Arc Second (30 m), Seamless Shuttle Radar Topography Mission (SRTM), edited by: U.S.G. Survey, Reston USA, US Geological Survey, 2007.

Wilhite, D. A. and Glantz, M. H.: Understanding the Drought Phenomenon: The Role of Definitions, Water Int., 10, 111-120, doi:10.1080/02508068508686328, 1985.

WWAP, World Water Assessment Programme: The United Nations World Water Development Report 3: Water in a Changing World, Paris, UNESCO, and London, Earthscan, 318 pp., 2009.

Yoo, J., Kwon, H. H. K., Kim, T. W., and Ahn, J. H.: Drought frequency analysis using cluster analysis and bivariate probability distribution, J. Hydrol., 420-421, 102-111, doi:10.1016/j.jhydrol.2011.11.046, 2012. 